\title{
Understanding The Conceptual Definitions of Cost, Price, Worth
} and Value.

\author{
${ }^{1}$ Sunday Emmanuel Olajide ${ }^{2}$ MohdLizam ${ }^{3}$ Esther Bola Olajide \\ ${ }^{1-2}$ Department Of Real Estate, Faculty Of Technology Management and Business, UniversitiTun \\ Hussein Onn Malaysia. \\ ${ }^{3}$ Department Of Estate Management, School Of Environmental Studies, The federal Polytechnic, Ado- Ekiti, \\ Nigeria.
}

\begin{abstract}
Value, cost, worth and price are words in real estate practice and education that have been interchangeably used without much recourse to their relationships and sharp differences which may be detrimental to value determination. The literature on this subject appears to be scarce. Hence, it is the intention of this article to bring to fore the in-depth of their relationship and differences. Necessary information was derived from secondary data through article literature published in Google Scholar, Scopus, ScienceDirect, Ebscohost and a host of others. Findings showed that though the concepts are related, their differences cannot be undermined. The findings of this article would be useful to the real estate stakeholders including the academic circle.
\end{abstract}

Keywords: Concept, cost, price, value, worth.

\section{INTRODUCTION}

A market is a medium whereby products and services including real estate investment are transacted which are different in many respects. The first thing that comes to mind, anytime we go and buy a product is, what is the price of the good or service? How much does it cost? What is the worth of it? What is its value for us? Ordinarily more often, these four questions seem similar, but however these four terms: price, cost, worth and value hold different meanings which would be carefully distinguished in this article.

Essentially, this subject can be viewed from different perspectives like marketing, economics, philosophy and what have you, hence, it is expedient to state that the discussion in this paper though could be extended or applied to other fields, is aimed to be centered on real estate transactions which include estate appraisal, estate agency, real estate valuation, property development, property rating and taxation among others. Also, it is necessary to mention that the main subject matter in this discussion is value. Over the years, there had been a definitional misconception between value and other terms like cost, price, and worth within the academia and practice. This article attempts to consider available relevant literature to unveil their relationships and differences.

Value as a concept is said to be ambiguous as it connotes different meanings, classifications and theories (Dietrich, 2000). Market value is, however, central to this article. Market value has been variously defined as the highest price estimates in terms of money which the property would bring if displayed for sale in the open market allowing an ample time to locate a buyer who purchases with the knowledge of all the uses to which it is adapted and for which it is proficient of being used (McParland, McGreal, \& Adair, 2000).

The concepts of worth, cost and price and their relationship to value (as shown in Figure 1) are fundamental issues within the operation and regulation of real estate market (Fishman, 2013). If a dictionary is considered, the words worth, cost, price, and value are normally found to be described as synonymous or have definitions that are at least in part interchangeable. Also in some countries, there may be little or no distinction made between these words (Adair, et al., 1996). There may be significant differences in practice; for instance in the UK and Malaysia, valuations are undertaken by a valuer and an appraisal is undertaken by an appraiser or property investment surveyor advising the purchaser or employed by the purchaser (Ambar\& Omar, 2013), whereas in the US an appraiser undertakes both valuation and investment appraisal as it is in other countries like Nigeria (Iroham, et al, 2013).

However, in UK in the recent years, the distinction in the meaning of worth, price, cost and value has become an important matter in defining the activity of the real estate professional. Essentially, until recently, most professionals operating in real estate would have used the words price, worth, cost and value interchangeably. In response to this, in the early 1990s, the emphasis on valuation accuracy in the UK was intense (Mackmin, 2013; Lizieri and Venmore-Rowland, 1993; Matysiak and Venmore-Rowland, 1995), and debate focused on the need for the consultant valuer/appraiser to be in tune with the needs of the client; an issue 
raised by Mallinson (Brown, Matysiak\& Shepherd,1998). Mallinson was of the view that some different bases of valuation were required and that a distinction should be drawn between the value in exchange (market value) and value in use (worth). In response to this, Royal Institution of Chartered Surveyors (RICS) produced two guides: one to commercial valuations (McParland, McGreal, \& Adair, 2000) and the other on worth (Baum \& Crosby, 2014). Since then, the understanding of a differential between the terms has developed. In the same vein, it is the intention of this article to further expatiates on their differences and relationships.

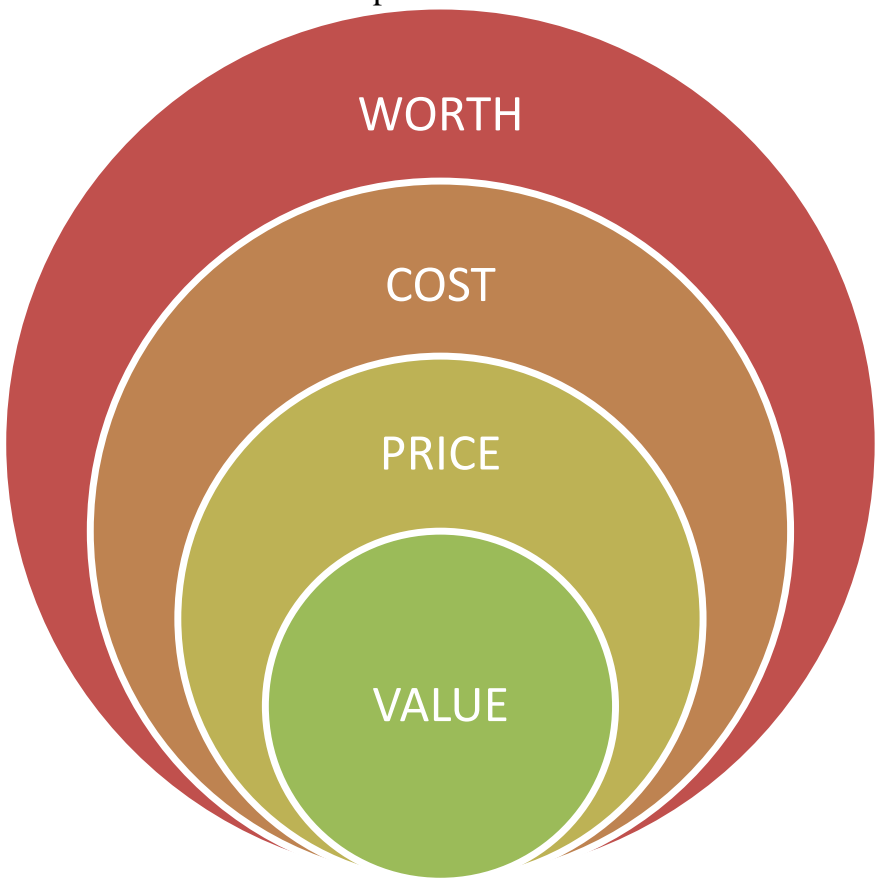

FIG. 1: INTERRELATIONSHIP OF PRICE, COST, WORTH AND VALUE

\section{LITERATURE REVIEW}

From existing literature, efforts had been made by researchers to render different definitions in respect of the terms in question, that is, price, cost, worth and value. The authors of this article have examined these varied views and summarily present them subsequently.

Surbhi (2014) defines price, cost, worth and value in the following order: price as the amount of money expended by the buyer to the seller in exchange for any product and service, that is, the amount charged by the willing seller for a commodity is referred to as its price, which includes cost and the profit margin. Cost, according to him is the amount incurred on the inputs like land, labour, capital, enterprise, etc., for producing any product, that is, it is the amount of money spent by the company in the manufacturing of a product. The worth of a commodity is defined as an expected selling price of some form of property, an appraisal, that is, worth is usually a subjective view of the seller, and speculating about a likely sale, or probable cost to replace his property. Value, on the other hand, is the usefulness of any product to a customer which is usually not expressed in monetary terms but varies from customer to customer.

Attempting to bring out the differences in value, worth, price and cost, Parker (2015) described value as the estimate of an amount assuming- exchange, specific date, buyer willing to buy, seller willing to buy, no buyer-seller relationship, period of marketing has occurred, and parties had each acted knowledgeably, prudently and without compulsion; Worth is seen as the value of a commodity to the owner or a potential owner for individual investment or operational objectives. Parker (2015) sees price as the amount asked, offered or paid for an asset, hence, because of the financial abilities, motivations or special interests of a given seller or buyer, the price offered may be different from the value which might be offered to the asset by others; while cost according to him is the amount required to create or acquire the asset and when the asset has been acquired or created, its cost is a fact. According to him, a price is related to cost due to the fact that the price paid for a commodity becomes its cost to the purchaser.

Olajide, et al (2016) posited that on a normal setting value and cost are supposed to be directly opposite each other in that while value tends toward measuring the aggregate of the present worth of future benefit,; cost on the other hand measures past sacrifice regarding labour or materials or both. Value according to them is the measure of future rights to income, which one anticipates as a result of ownership or utilization while cost is the price which is paid for value. They further reiterated that the market value of a product must exceed or equal its production cost over time if producers are going to have the incentive to continue production. In other words, 
they mean value is concerned with the degree of utility derivable from a product over time while cost is concerned with measuring what it takes to produce a unit of product. However, Olajide, et al. identified few situations where value and cost may tend to overlap. Such instances they noted include where the supply of a product is higher than its demand; where a product is newly introduced to the market and for properties that are not usually found in the market like church, shrine, cemetery and the likes- the approach to the absence of comparable is to take their value from the cost point of view since they are rarely sold or bought.

Essentially, a careful review of these opinions have shown that the terms; price, cost, and worth though closely related to value are distinctively difference, hence, the need for this review.

\section{RESULT AND DISCUSSION}

Deducing from the reviewed literature, the key differences between the terms can be summarized as follows: Price is what you pay for goods or services you receive, cost is the amount of inputs acquired in producing a commodity and value is what goods or services pay you, that is, worth. Price is measured in numerical terms, cost is also calculated in numerical terms, but worth and value can never be calculated in numbers. Price and cost are same for all the customers, while value varies from customer to customers and worth is subjective to every owner. Price is determined by the price policy, cost is calculated on expenditure actually incurred on producing a particular product but the estimation of worth and value are based on owner's and customer's opinions respectively. The fluctuations in the market will affect price and cost but worth and value remain unaffected. Price is ascertained with the view of the customers; cost is ascertained from producer's view; worth is ascertained from the owner's point of view whereas the ascertainment of value is done from the user's point of view. This can further be explained through the comparison chart in Table 1.

Table 1 Comparison Chart

\begin{tabular}{|l|l|l|l|l|}
\hline $\begin{array}{l}\text { BASIS OF } \\
\text { COMPARISON }\end{array}$ & VALUE & PRICE & COST & WORTH \\
\hline MEANING & $\begin{array}{l}\text { Value is the } \\
\text { utility of a } \\
\text { good or } \\
\text { service. }\end{array}$ & $\begin{array}{l}\text { Price is the } \\
\text { amount paid } \\
\text { for acquiring } \\
\text { any product } \\
\text { or service. }\end{array}$ & $\begin{array}{l}\text { Cost is the } \\
\text { amount } \\
\text { incurred in } \\
\text { producing and } \\
\text { manufacturing } \\
\text { a product. }\end{array}$ & $\begin{array}{l}\text { Worth is the } \\
\text { subjective } \\
\text { process of } \\
\text { estimating } \\
\text { the value of } \\
\text { an asset. }\end{array}$ \\
\hline ESTIMATION & $\begin{array}{l}\text { Through } \\
\text { opinion }\end{array}$ & $\begin{array}{l}\text { Through } \\
\text { policy }\end{array}$ & Through fact & $\begin{array}{l}\text { Through } \\
\text { subjective } \\
\text { view }\end{array}$ \\
\hline ASCERTAINMENT & $\begin{array}{l}\text { Value is } \\
\text { ascertained } \\
\text { from the } \\
\text { user's } \\
\text { perspective }\end{array}$ & $\begin{array}{l}\text { Price is } \\
\text { ascertained } \\
\text { from the } \\
\text { customer's } \\
\text { perspective }\end{array}$ & $\begin{array}{l}\text { Cost is } \\
\text { ascertained } \\
\text { from the } \\
\text { producer's } \\
\text { perspective }\end{array}$ & $\begin{array}{l}\text { Worth is } \\
\text { ascertained } \\
\text { from the } \\
\text { owner's } \\
\text { perspective }\end{array}$ \\
\hline MONEY & $\begin{array}{l}\text { It is rarely } \\
\text { calculated in } \\
\text { terms of } \\
\text { money }\end{array}$ & $\begin{array}{l}\text { It can be } \\
\text { calculated in } \\
\text { terms of } \\
\text { money }\end{array}$ & $\begin{array}{l}\text { It can be } \\
\text { calculated in } \\
\text { terms of } \\
\text { money }\end{array}$ & $\begin{array}{l}\text { It is not } \\
\text { calculated in } \\
\text { terms of } \\
\text { money }\end{array}$ \\
\hline $\begin{array}{l}\text { IMPACT OF } \\
\text { VARIATIONS IN } \\
\text { MARKET }\end{array}$ & $\begin{array}{l}\text { Value } \\
\text { remains } \\
\text { unchanged }\end{array}$ & $\begin{array}{l}\text { Price of } \\
\text { product } \\
\text { increase or } \\
\text { decrease }\end{array}$ & $\begin{array}{l}\text { Cost of inputs } \\
\text { rise or fall. }\end{array}$ & $\begin{array}{l}\text { Worth } \\
\text { remains } \\
\text { unchanged }\end{array}$ \\
\hline
\end{tabular}

Additionally, the following examples are given to further drive home the differentiation.

Price versus cost: If you purchase a new house, then, the amount you pay to the house seller for its acquisition is its price while the amount invested in building the house is its cost. Normally, the price of any commodity is more than its cost because the price covers the profit margin.

Cost versus Value: If you are a builder that constructs hundreds of houses on a regular basis, then, the cost of producing is one's prior concern and not the value of the commodity. You may try to achieve the economies of scale, that is, more production at less cost. Whereas in the case of the customer, the purpose for which the house is obtained must be fulfilled irrespective of the cost incurred in its production. A customer must feel the worth of purchasing the house in terms of its price. 
Value and price: This can be easily explained with the popular example given by Professor Adam Smith relating to diamond and water (Sinha, 2013). Water is more important for human survival, yet, it is of low price, while the diamond is just used for adornment and nobody dies without it, is priced very high. The rationale behind this is its value, as the value of water is much for us, it is obtainable at a low price whereas, the value of a diamond is less for us, and therefore, it is priced at a higher rate.

Price versus worth: Price and worth could be similar but a true price only subsists when we are truly selling, whereas we can predict about worthat any time. Likewise, if we really do sell, and prices are negotiable, we will set our price higher than what we think it is worth. For instance, if a house is listed for sale, and during negotiation, the seller/developer considering his sacrifices and profit margin insisting on selling at $\$ 200,000$ while the buyer is offering $\$ 175,000 ; \$ 200,000$ is worth, and $\$ 175,000$ is the price at least to the buyer. Regarding value, we think of worth as being consistent across market price changes, and so as somewhat intrinsic in the thing. We tend to imagine a perfect purchaser, one who values the asset as least as much as we do. If sale prices decline to align with our anticipation, we may have to adjust our conception of worth; this could be done without having to change our judgment of value, what it is "worth to me."

Value versus worth: Value (valuation) is the estimation of the price at which a commodity will sell at a given point in time while worth or investment value is the subjective process of determining the value of an asset given the particular circumstances of an opinion of individuals or relative to the market price. Value and worth could have been perfectly the same except for the fact that market value is assessed objectively while worth is intrinsic, that is subjective in assessment. When a seller insists on how much to sell his good or service without any recourse to the interest of the buyer, it is no longer value but worth.

\section{CONCLUSION}

After discussing extensively on these four (4) terms, one must found out the answers to the four questions asked at the beginning of this article. From the preceding, the need for an update in the conceptual definitions of the terms: price, worth, cost and value have been carefully highlighted especially within the real estate practice and education. So far so good, even though the terms could sometimes be related their differences can be succinctly summarized as follows: Price is what you pay for any asset you procured; cost is the amount of inputs acquired in producing a product; worth is the value of a commodity to the owner or a potential owner for individual investment or operational objectives and value is what goods and services pay you, that is, worth. The key difference between value and worth is that assessment of value is mostly objective but worth is purely subjective-intrinsic. Price is measured in numerical terms, cost is as well measured in numerical terms, value and worth can never be calculated in numbers. Price and cost are the same for all customers, but value and worth vary from customer to customer. Price is determined by the price policy; cost is estimated on actual amount expended on producing a particular commodity, but estimation of value and worth are based on customer's opinion. Furthermore, the fluctuations in the market will affect the price and the cost of any product while value and worth remain unaffected. Price is ascertained with the view of a customer; the cost is ascertained from producer's view; whereas the ascertainment of value and worth is done from the users' point of view.

The policy implication of this research is to throw lime light on the concepts for the purpose of knowledge impartation in academic institutions and for better understanding among players in the property market.

\section{REFERENCES}

[1] Adair, A., Hutchison, N., MacGregor, B., McGreal, S., \&Nanthakumaran, N. (1996). An analysis of valuation variation in the UK commercial property market: Hager and Lord revisited. Journal of Property Valuation and Investment, 14(5), 34-47.

[2] Ambar, A., \& Omar, A. J. (2013). Best practices for Corporate Real Estate Management (CREM) in Malaysia: value-added CREM strategies among Malaysian corporations.

[3] Baum, A. E., \& Crosby, N. (2014). Property investment appraisal.John Wiley \& Sons.

[4] Brown, G. R., Matysiak, G. A., \& Shepherd, M. (1998).Valuation uncertainty and the Mallinson Report. Journal of Property Research, 15(1), 1-13.

[5] Dietrich, J. R., Harris, M. S., \& Muller, K. A. (2000). The reliability of investment property fair value estimates. Journal of Accounting and Economics, 30(2), 125-158.

[6] Fishman, J. E. (2013). Standards of value: theory and applications. John Wiley \& Sons.

[7] Iroham, C. O., Ogunba, O. A., Oloyede, S. A., \&Omirin, M. M. (2013).Factors Affecting the Usage of Major Heuristics in Nigeria Property Investment Valuation. Journal of Sustainable Development Studies, 4(2), 114. 
[8] Lizieri, C., \&Venmore-Rowland, P. (1993). Valuations, prices and the market: a rejoinder. Journal of Property Research, 10(2), 77-84.

[9] Mackmin, D. (2013). Valuation and Sale of Residential Property.Taylor \& Francis.

[10] Matysiak, G., \& Wang, P. (1995). Commercial property market prices and valuations: analysing the correspondence. Journal of Property Research,12(3), 181-202.

[11] McParland, C., McGreal, S., \& Adair, A. (2000).Concepts of price, value and worth in the United Kingdom-Towards a European perspective. Journal of Property Investment \& Finance, 18(1), 84-102.

[12] Olajide, S., Bello, K. \&Alabi, O. T. (2016) Elements of Estate Management and Property Valuation.ABISAMPrintz, Lagos, Nigeria. $5^{\text {th }}$ Edition pp. 71-79

[13] Parker, D. (2015) Contemporary Global Property Management Issues. Being technical paper presented to the post graduate students, Faculty of Technology Management and Business. UniversitiTun Hussein Onn Malaysia.

[14] Seiler, M., Webb, J., \& MYER, N. (1999). Diversification issues in real estate investment. Journal of Real Estate Literature, 7(2), 163-179.

[15] Sinha, A. (2013). Theories of Value from Adam Smith to PieroSraffa.Routledge.

[16] Surbhi, S. (2014) Differences between price, cost and value.Worldthinknest and lightest business notebook. Keydifference.com HP EliteBook Folio, November, 12

[17] The University of Reading (2009) Real Estate Investment Appraisal.Some Background Reading.Department of Real Estate and Planning.www.reading.ac.uk/rep downloaded on the 14th April, 2016. 